JURAL

PENELITIAN

PERIKANAN

INDONESIA

e-ISSN 2502 - 6542 


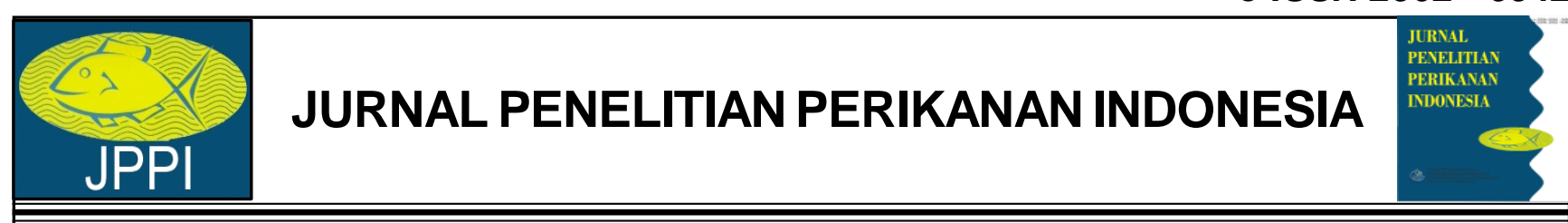

Volume 23 Nomor 1 Maret 2017

Nomor Akreditasi: 653/AU3/P2MI/LIPI/07/2015

(Periode: Agustus 2015 - Agustus 2018)

Jurnal Penelitian Perikanan Indonesia adalah wadah informasi perikanan,

baik laut maupun perairan umum daratan. Jurnal ini menyajikan hasil penelitian sumber daya,

penangkapan, oseanografi, lingkungan, rehabilitasi lingkungan dan pengkayaan stok ikan.

Terbit pertama kali tahun 1994. Tahun 2006, frekuensi penerbitan Jurnal ini tiga kali dalam setahun pada bulan April, Agustus, dan Desember.

Tahun 2008, frekuensi penerbitan menjadi empat kali yaitu pada bulan MARET, JUNI, SEPTEMBER, dan DESEMBER.

\section{Ketua Penyunting:}

Prof. Dr. Ir. Wudianto, M.Sc. (Teknologi Penangkapan Ikan-Pusat Riset Perikanan)

\section{Anggota Penyunting:}

Dr. Wijopriono (Hidro Akustik Perikanan-Pusat Riset Perikanan)

\section{Dewan Penyunting:}

Prof. Dr. Ir. Ngurah Nyoman Wiadnyana, DEA. (Ekologi Perairan-Pusat Riset Perikanan)

Prof. Dr. Ir. Husnah, M. Phil. (Taksikologi-Pusat Riset Perikanan)

Prof. Dr. Ali Suman (Biologi Perikanan Udang-Balai Riset Perikanan Laut)

Dr. Eko Sriwiyono, S.Pi, M.Si. (Teknologi Kapasitas Penangkapan Ikan-Institut Pertanian Bogor)

Dr. Ir. Dewa Gede Raka Wiadnya, M.Sc. (Lingkungan dan Sumber Daya Ikan-Universitas Brawijaya)

\section{Editing Bahasa:}

Ir. Badrudin, M.Sc. (Dinamika Populasi Ikan-Komisi Nasional Pengkajian Stok Ikan)

\section{Penyunting Pelaksana: \\ Dra. Endang Sriyati \\ Darwanto, S.Sos. \\ Amalia Setiasari, A.Md.}

Administrasi:

Arief Gunawan, S. Kom

\section{Alamat Redaksi/Penerbit:}

Pusat Riset Perikanan

Jl. Pasir Putih II Ancol Timur Jakarta Utara 14430

Telp. (021) 64700928, Fax. (021) 64700929

Website : http://ejournal-balitbang.kkp.go.id/index.php/jppi

e-mail:jppi.puslitbangkan@gmail.com

Jurnal Penelitian Perikanan Indonesia diterbitkan oleh Pusat Riset Perikanan - Badan Riset dan Sumber Daya Manusia Kelautan dan Perikanan-Kementerian Kelautan dan Perikanan. 


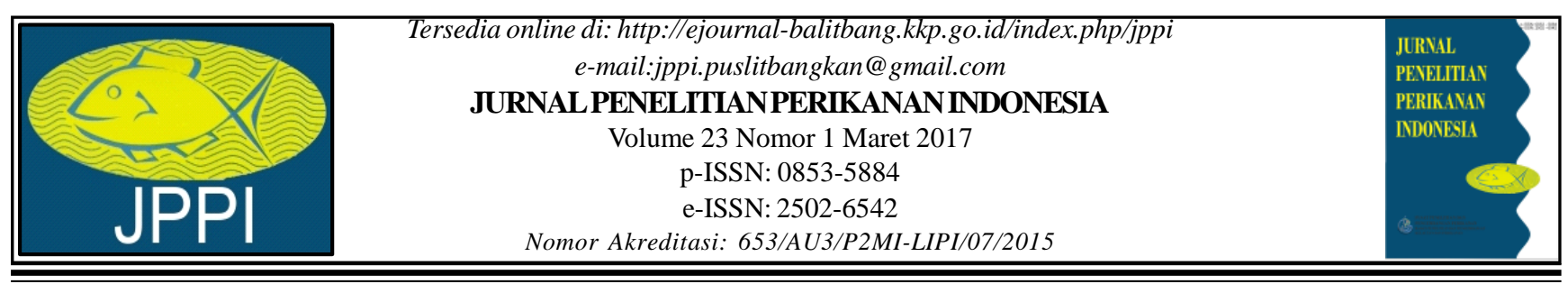

\section{LEMBAR INDEKSASI}

\section{FOKUS DAN RUANG LINGKUP JURNAL PENELITIAN PERIKANAN INDONESIA}

Jurnal Penelitian Perikanan Indonesia (http://ejournal-balitbang.kkp.go.id/index.php/jppi) memiliki p-ISSN 0853-5884; eISSN 2502-6542 dengan Nomor Akreditasi: 653/AU3/P2MI-LIPI/07/2015 (Periode Agustus 2015-Agustus 2018). Terbit pertama kali tahun 1994. Tahun 2006, frekuensi penerbitan tiga kali dalam setahun pada bulan April, Agustus dan Desember. Tahun 2008, frekuensi penerbitan menjadi empat kali yaitu pada bulan Maret, Juni, September dan Desember.

Jurnal Penelitian Perikanan Indonesia adalah wadah informasi perikanan, baik laut maupun perairan umum daratan. Jurnal ini menyajikan hasil penelitian sumber daya, penangkapan, oseanografi, lingkungan, rehabilitasi lingkungan dan pengkayaan stok ikan.

Naskah yang diterbitkan di Jurnal Penelitian Perikanan Indonesia telah melalui pemeriksaan pedoman penulisan oleh Administrasi Jurnal, naskah yang sudah mengikuti pedoman penulisan direview oleh 2 (dua) orang Dewan Penyunting dan 1 (satu) orang Bebestari (Peer-Reviewer) berdasarkan penunjukan dari Ketua Dewan Penyunting. Keputusan diterima atau tidaknya suatu naskah menjadi hak dari Ketua Dewan Penyunting berdasarkan atas rekomendasi dari Dewan Penyunting dan Bebestari.

\section{INFORMASI INDEKSASI JURNAL}

Jurnal Penelitian Perikanan Indonesia (http://ejournal-balitbang.kkp.go.id/index.php/jppi) memiliki p-ISSN 0853-5884; eISSN 2502-6542 yang sudah terindeks di beberapa pengindeks bereputasi, antara lain: Cross Ref, Indonesian Scientific Journal Database (ISJD), SCILIT, Sherpa/Romeo, Google Scholar, Directory Open Access Journals (DOAJ), Bielefeld Academic Search Engine (BASE), British Library One Search dan Lancaster University.
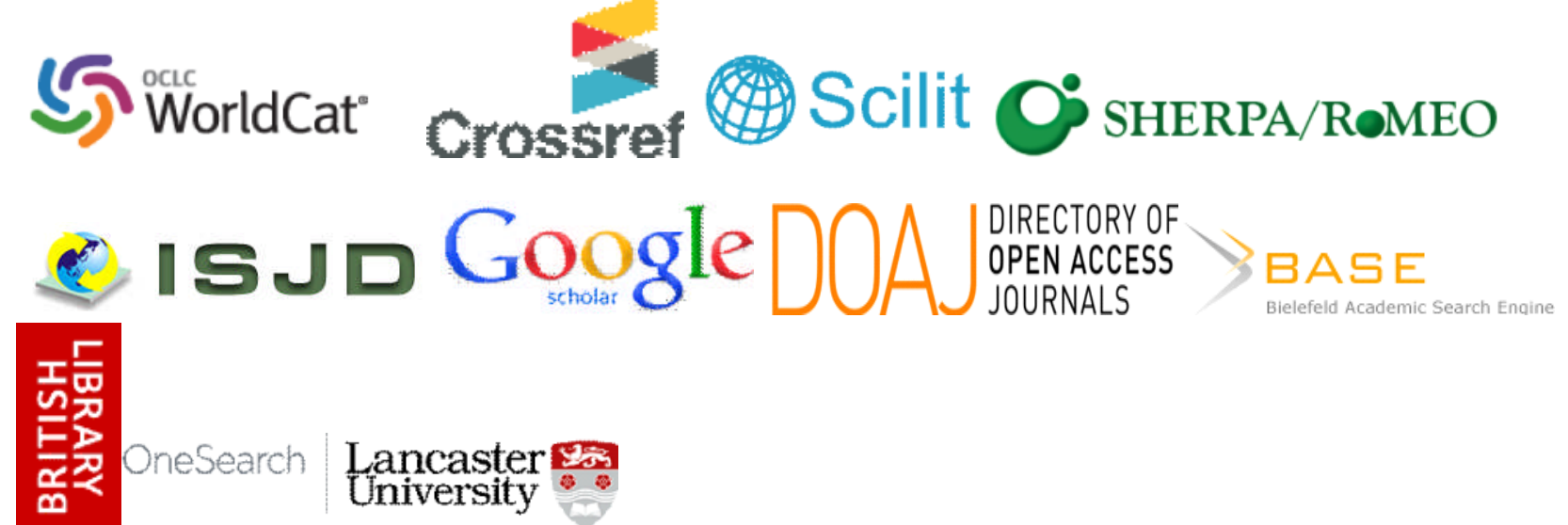


\section{BEBESTARI PADA JURNAL PENELITIAN PERIKANAN INDONESIA}

1. Prof. Dr. Ir. Husnah, M. Phil. (Toksikologi-Pusat Riset Perikanan)

2. Ir. Badrudin, M.Sc. (Dinamika Populasi Ikan-Komisi Nasional Pengkajian Stok Ikan)

3. Prof. Dr. Ir. Sam Wouthuyzen, M. Sc. (Oseanografi Perikanan-Lembaga IImu Pengetahuan Indonesia)

4. Prof. Dr. Ir. Endi Setiadi Kartamihardja, M. Sc. (Pengelolaan Perikanan PUD-Pusat Riset Perikanan)

5. Prof. Dr. Ir. Ari Purbayanto, M. Si. (Metode Penangkapan Ikan-Institut Pertanian Bogor)

6. Prof. Dr. Ir. Indra Jaya (Hidro Akustik Perikanan-Institut Pertanian Bogor)

7. Prof. Dr. Ir. John Haluan, M. Sc. (Sistem Informasi Perikanan-Institut Pertanian Bogor)

8. Prof. Dr. Ali Suman (Biologi Perikanan Udang-Balai Riset Perikanan Laut)

9. Prof. Dr. Ir. M.F. Rahardjo (Iktiologi, Ekologi Ikan, Konservasi Sumber Daya Hayati Perairan-Institut Pertanian Bogor)

10. Prof. Dr. Ir. Setyo Budi Susilo, M.Sc. (Penginderaan Jauh-Institut Pertanian Bogor)

11. Prof. Dr. Ir. Gadis Sri Haryani (Limnologi-Lembaga IImu Penelitian Indonesia)

12. Prof. Dr. Ir. Mennofatria Boer, DEA. (Matematika dan Statistika Terapan-Institut Pertanian Bogor)

13. Prof. Dr. Ir. Janny Dirk Kusen, MSc, (Biologi Kelautan - Universitas Sam Ratulangi)

14. Dr. Ir. Mochammad Riyanto, M.Si. (Teknologi Penangkapan Ikan-Institut Pertanian Bogor)

15. Dr. Purwito Martosubroto, M.Sc. (Dinamika Populasi Ikan-Komisi Nasional Pengkajian Stok Ikan)

16. Ir. Sasanti R. Suharti M.Sc. (Biologi Kelautan-Lembaga IImu Penelitian Indonesia)

17. Dr. Ir. Sudarto, M.Si. (Genetika Populasi-BP2BIH)

18. Dr. Ir. Mohammad Mukhlis Kamal, M. Sc. (Biologi Konservasi Perairan-Institut Pertanian Bogor)

19. Dr. Estu Nugroho (Sumber Daya Genetik Ikan-Pusat Riset Perikanan)

20. Dr. Ir. Zairion, M. Sc. (Pengelolaan Sumber Daya Perikanan-Institut Pertanian Bogor)

21. Dr. Ir. Zainal Arifin, M.Sc. (Kimia Oseanografi-Lembaga Ilmu Penelitian Indonesia)

22. Dr. Ir. Mas Tri Djoko Sunarno, MS. (Nutrisi-Balai Riset Perikanan BudidayaAir Tawar dan Penyuluhan Perikanan)

23. Dr. Ir. Abdul Ghofar, M. Sc. (Pengkajian Stok Sumber Daya Ikan-Universitas Diponogoro)

24. Drs. Suwarso, M.Si. (Sumber Daya Lingkungan-Balai Riset Perikanan Laut)

25. Drs. Bambang Sumiono, M. Si. (Biologi Perikanan-Pusat Riset Perikanan)

26. Ir. Duto Nugroho, M.Si. (Teknologi Penangkapan Ikan-Pusat Riset Perikanan)

27. Dr. Ir. Andin Taryoto, M.Si. (Sosiologi Perikanan-Sekolah Tinggi Perikanan)

28. Dr. Priyanto Rahardjo, M.Sc. (Biologi Konservasi-Sekolah Tinggi Perikanan)

29. Dr. Ir. Ario Damar, M.Si. (Ekologi Perairan Pesisir, Phytoplankton Ekologi-Institut Pertanian Bogor)

30. Dr. Ir. Dewa Gede Raka Wiadnya, M.Sc, (Lingkungan dan Sumberdaya Ikan-Universitas Brawijaya)

31. Dr. Fayakun Satria, M.App.Sc. (Sumberdaya dan Lingkungan Perikanan-Balai Riset Perikanan Laut) 


\section{UCAPAN TERIMAKASIH}

Ketua Penyunting Jurnal Penelitian Perikanan Indonesia (JPPI) mengucapkan terima kasih kepada para Bebestari yang telah berpartisipasi dalam menelaah naskah yang diterbitkan di jurnal ilmiah ini, sehingga jurnal ini dapat terbit tepat pada waktunya. Bebestari yang berpartisipasi dalam terbitan Volume 23 Nomor 1 Maret 2017 adalah:

1. Ir. Badrudin, M.Sc. (Dinamika Populasi Ikan-Komisi Nasional Pengkajian Stok Ikan)

2. Prof. Dr. Ir. Janny Dirk Kusen, MSc, ( Biologi Kelautan - Universitas Sam Ratulangi)

3. Prof. Dr. Ir. Mennofatria Boer, DEA. (Matematika dan Statistika Terapan-Institut Pertanian Bogor)

4. Drs. Bambang Sumiono, M. Si. (Biologi Perikanan-Pusat Riset Perikanan)

5. Dr. Fayakun Satria, M.App.Sc. (Sumberdaya dan Lingkungan Perikanan-Balai Riset Perikanan Laut) 


\section{KATAPENGANTAR}

Jurnal Penelitian Perikanan Indonesia (JPPI) di tahun 2017 memasuki Volume ke-23. Proses penerbitan jurnal ini dibiayai oleh Pusat Riset Perikanan tahun anggaran 2017. Semua naskah yang terbit telah melalui proses evaluasi oleh Dewan Penyunting dan Bebestari serta editing oleh Penyunting Pelaksana.

Penerbitan kesatu di Volume 23 Nomor 1 tahun 2017 menampilkan tujuh artikel hasil penelitian perikanan di perairan Indonesia. Ketujuh artikel tersebut mengulas tentang: Faktor-Faktor yang Mempengaruhi Kepatuhan Nelayan Tanjungbalai Asahan dalam Mendukung Perikanan yang Berkelanjutan; Karakteristik Populasi Udang Jerbung (Penaeus merguiensis de Man, 1888) di Perairan Cilacap dan Sekitarnya; Analisis Produktivitas dan Suseptibilitas pada Tuna Neritik di Perairan Pelabuhanratu; Kelimpahan Stok Ikan Layur (Trichiurus spp.) dan Faktor Lingkungan yang Mempengaruhinya di Perairan Palabuhanratu, Jawa Barat; Dinamika Populasi dan Tingkat Pemanfaatan Udang Windu (Penaeus semisulcatus de Haan, 1844) di Perairan Balikpapan; Distribusi dan Potensi Sumber Daya Ikan Pelagis di Wilayah Pengelolaan Perikanan Negara Republik Indonesia 573 (WPP NRI 573) Samudera Hindia; Aplikasi Model Surplus Produksi Non-Ekuilibrium pada Perikanan Layang (Decapterus macrosoma) di Laut Jawa.

Diharapkan tulisan ini dapat memberikan kontribusi bagi para pengambil kebijakan dan pengelola sumber daya perikanan di Indonesia. Ketua Penyunting mengucapkan terima kasih atas partisipasi aktif para peneliti dari lingkup dan luar Pusat Riset Perikanan. 


\section{JURNAL PENELITIAN PERIKANAN INDONESIA \\ Volume 23 Nomor 1 Maret 2017}

\section{DAFTAR ISI}

Halaman

DAFTAR BEBESTARI

UCAPAN TERIMA KASIH ii

KATA PENGANTAR iii

DAFTAR ISI

Faktor-Faktor yang Mempengaruhi Kepatuhan Nelayan Tanjungbalai Asahan dalam Mendukung Perikanan yang Berkelanjutan

Oleh: Benardo Nababan, Eko Sri Wiyono dan Mustaruddin.....

Karakteristik Populasi Udang Jerbung (Penaeus merguiensis de Man, 1888) di Perairan Cilacap dan Sekitarnya

Oleh: Ali Suman dan Budi Iskandar Prisantoso.

Analisis Produktivitas dan Suseptibilitas pada Tuna Neritik di Perairan Pelabuhanratu

Oleh: Eva Suryaman, Mennofatria Boer, Luky Adrianto dan Lilis Sadiyah.

Kelimpahan Stok Ikan Layur (Trichiurus spp.) dan Faktor Lingkungan yang Mempengaruhinya di Perairan Palabuhanratu, Jawa Barat

Oleh: Wijopriono dan Mohamad Adha Akbar.

Dinamika Populasi dan Tingkat Pemanfaatan Udang Windu (Penaeus semisulcatus de Haan, 1844) di Perairan Balikpapan

Oleh: Tirtadanu, Wedjatmiko dan Pratiwi Lestari.....

Distribusi dan Potensi Sumber Daya Ikan Pelagis di Wilayah Pengelolaan Perikanan Negara Republik Indonesia 573 (WPP NRI 573) Samudera Hindia

Oleh: Asep Ma'mun, Asep Priatna, Thomas Hidayat dan Nurulludin.

Aplikasi Model Surplus Produksi Non-Ekuilibrium pada Perikanan Layang (Decapterus macrosoma) di Laut Jawa

Oleh: Suherman Banon Atmadja, Bambang Sadhotomo dan Duto Nugroho. 


\section{JURNAL PENELITIAN PERIKANAN INDONESIA Vol. 23 No.1 Maret 2017}

\section{KUMPULAN ABSTRAK}

\section{FAKTOR-FAKTOR YANG MEMPENGARUHI KEPATUHAN NELAYAN TANJUNGBALAI ASAHAN DALAM MENDUKUNG PERIKANAN YANG BERKELANJUTAN}

Benardo Nababan

JPPI Maret 2017, Vol 23 No. 1, Hal. 1-10

\section{ABSTRAK}

Evaluasi terhadap kepatuhan nelayan sangat diperlukan karena manajemen perikanan merupakan kegiatan yang berfokus pada sumber daya manusia dan aktivitasnya di bidang perikanan. Pengelola harus benar-benar memahami bagaimana nelayan atau stakeholder perikanan merespon segala peraturan yang dibuat. Penelitian ini bertujuan untuk menentukan faktor-fakor yang mempengaruhi kepatuhan nelayan dalam mendukung perikanan yang berkelanjutan ditinjau dari aspek persepsi dan karakteristik sosial-ekonomi. Metode yang digunakan ialah analisis model persamaan structural. Dalam analisis ini digunakan 4 variabel laten, yaitu karakteristik sosial-ekonomi nelayan, persepsi terhadap kriteria alat penangkapan ikan yang ramah lingkungan, persepsi terhadap keberadaan sumber daya ikan, dan kepatuhan terhadap aturan. Hasil penelitian menunjukkan bahwa faktor-faktor yang mempengaruhi kepatuhan nelayan, yaitu: karakteristik sosial-ekonomi nelayan (organisasi, sosialisasi, investasi, dan pendapatan), persepsi terhadap kriteria alat penangkapan ikan yang ramah lingkungan, dan persepsi terhadap keberadaan sumber daya ikan. Untuk meningkatkan kepatuhan nelayan dapat dilakukan beberapa upaya, seperti: mendorong dan memfasilitasi nelayan untuk terlibat dalam organisasi kenelayanan, memberikan sosialisasi terkait pengelolaan perikanan berkelanjutan, meningkatkan ukuran kapal yang digunakan nelayan, dan memberikan bantuan permodalan yang diharapkan mampu meningkatkan pendapatan.

Kata Kunci: Berkelanjutan; kepatuhan nelayan; model persamaan struktural (SEM); persepsi

KARAKTERISTIK POPULASI UDANG JERBUNG (Penaeus merguiensis de Man, 1888) DI PERAIRAN CILACAP DAN SEKITARNYA

\section{Ali Suman}

JPPI Maret 2017, Vol 23 No. 1, Hal. 11-18

\section{ABSTRAK}

Tingginya permintaan pasar terhadap udang jerbung mengakibatkan aktivitas penangkapannya berlangsung secara terus-menerus sepanjang tahun sehingga mengancam kelestariannya. Penelitian karakteristik populasi merupakan salah satu dasar utama dalam merumuskan pengelolaan menuju pemanfaatannya secara lestari. Tujuan penelitian ini adalah untuk mengetahui karakteristik populasi udang jerbung di perairan Cilacap dan sekitarnya. Penelitian dilakukan dari bulan Januari sampai dengan Nopember 2013 dengan metode survey. Hasil penelitian menunjukkan bahwa ratarata ukuran panjang pertama kali matang kelamin (Lm) udang jerbung di perairan Cilacap dan sekitarnya adalah pada panjang karapas $38,3 \mathrm{~mm}$ dan musim pemijahan berlangsung sepanjang tahun dengan puncaknya pada bulan Januari. Laju pertumbuhan udang jerbung jantan adalah 1,00 per tahun dan panjang karapas maksimum $(\mathrm{L} \infty)$ adalah $40,7 \mathrm{~mm}$ serta untuk udang betina didapatkan nilai $\mathrm{K}$ adalah 1,10 per tahun dan nilai $\mathrm{L} \infty$ adalah $54,2 \mathrm{~mm}$. Laju kematian total (Z) udang jerbung jantan adalah 2,46 per tahun, laju kematian karena penangkapan $(F)$ dan laju kematian alami (M) masing-masing 1,37 per tahun dan 1,09 per tahun. Untuk udang betina didapatkan nilai $Z$ adalah 1,69 per tahun, nilai $F$ dan nilai $M$ masing-masing 0,61 dan 1,08 per tahun. Laju pengusahaan (E) udang jerbung jantan adalah 0,56 per tahun dan nilai $E$ udang betina adalah 0,36 per tahun. Pola penambahan baru udang jerbung di perairan Cilacap berlansung sepanjang tahun dengan puncaknya pada bulan Maret dan April. Tingkat pemanfaatan untuk udang jerbung jantan sudah berada dalam tahapan overfishing dan perlu dilakukan pengurangan jumlah upaya. Kata Kunci: Dinamika populasi; udang jerbung;
pemanfaatan; Cilacap

\section{ANALISIS PRODUKTIVITAS DAN SUSEPTIBILITAS PADA TUNA NERITIK DI PERAIRAN PELABUHANRATU}

Eva Suryaman

JPPI Maret 2017, Vol 23 No. 1, Hal. 19-28

\section{ABSTRAK}

Pada perikanan tuna, tuna neritik merupakan kelompok ikan yang dominan tertangkap pada perikanan pantai, termasuk perikanan skala kecil dan bersifat artisanal. Penangkapan ikan tuna neritik di perairan Palabuhanratu yang semakin intensif setiap tahunnya tanpa didasari pengelolaan yang tepat, diduga akan mengakibatkan terjadinya penurunan stok sumberdaya ikan. Penelitian ini bertujuan untuk menganalisa keberlanjutan spesies neritik tuna menggunakan analisis produktivitas dan suseptibilitas / Productivity and Susceptibility Analysis (PSA). Penelitian ini dilaksanakan dari Februari hingga Mei 2016 di perairan Palabuhanratu. Hasil penelitian menunjukan nilai kerentanan tuna neritik berturut-turut untuk ikan tenggiri 1,25; tongkol krai 1,37; 
tongkol abu-abu 0,91; tongkol komo 1,49; dan tongkol lisong 1,41. Hal ini menunjukan bahwa tingkat kerentanan ikan tuna neritik terhadap overfishing saat ini masih rendah karena nilainya masih dibawah 1,8, sehingga aktivitas penangkapan masih dapat ditingkatkan terutama untuk ikan tenggiri dan tongkol abu-abu yang memiliki kerentanan terendah.

Kata Kunci: Analisa produktivitas dan suseptibilitas; Palabuhanratu; tuna neritik; tingkat kerentanan

\section{KELIMPAHAN STOK IKAN LAYUR (Trichiurus spp.) DAN FAKTOR LINGKUNGAN YANG MEMPENGARUHINYA DI PERAIRAN PALABUHANRATU, JAWA BARAT}

\section{Wijopriono}

JPPI Maret 2017, Vol 23 No. 1, Hal. 29-36

\section{ABSTRAK}

Layur telah menjadi target utama penangkapan dan dieksploitasi secara intensif di perairan Palabuhanratu menyusul permintaan ekspor yang meningkat. Kajian dilakukan untuk mengetahui kelimpahan dan faktor lingkungan yang berperan terhadap fluktuasi hasil tangkapan ikan layur. Serial data hasil tangkapan dan upaya penangkapan bulanan 2004-2015 dan serial data iklim, yaitu SST, precipitasi, Dipole Mode Index (DMI), dan Southern Oscillation Index (SOI) dalam periode waktu yang sama digunakan untuk analisis. Hasil analisis menunjukkan bahwa peningkatan signifikan upaya penangkapan yang dilakukan sampai 2007 mengakibatkan hasil tangkapan per satuan upaya (CPUE) menurun secara konstan pada tahun-tahun berikutnya. Penurunan upaya penangkapan mencapai $28,5 \%$ pada tahun 2007 tidak dapat meningkatkan CPUE secara signifikan. Berdasarkan analisis forward seletion dalam model multiregresi, diketahui bahwa faktor iklim yang berperan dalam fluktuasi hasil tangkapan adalah presipitasi serta interaksi antara DMI dan SOI. Dalam kaitan tersebut perlu dilakukan pengaturan upaya penangkapan dan memperhitungkan variabilitas iklim dalam pengelolaan sumberdaya ikan layur di Palabuhanratu.

Kata Kunci: Layur; pancing ulur; kelimpahan; variabilitas iklim; Palabuhanratu

\section{DINAMIKA POPULASI DAN TINGKAT PEMANFAATAN UDANG WINDU (Penaeus semisulcatus de Haan, 1844) DI PERAIRAN BALIKPAPAN}

Tirtadanu

JPPI Maret 2017, Vol 23 No. 1, Hal. 37-45

\section{ABSTRAK}

Udang windu (Penaeus semisulcatus de Haan, 1844) di perairan Kalimantan Timur saat ini diduga berada dalam tahapan lebih tangkap, sehingga memerlukan kajian dinamika populasi yang lebih detail. Penelitian ini bertujuan untuk mengkaji dinamika populasi dan tingkat pemanfaatan udang windu sebagai dasar dalam pengelolaan perikanan udang di Balikpapan. Penelitian ini dilakukan pada FebruariNovember 2016. Metode yang digunakan adalah random sampling dengan analisis menggunakan model analitik. Hasil penelitian menunjukkan ukuran panjang karapas asimptotik (CLo) udang jantan sebesar 47,5 mmCL dengan laju pertumbuhan $(\mathrm{K})$ 1,72 per tahun dan panjang karapas asimptotik (CLod) udang betina 53,7 mmCL dengan laju pertumbuhan $(K)$ 1,53 per tahun. Ukuran rata-rata pertama kali tertangkap udang (Lc) sebesar 31,5 $\mathrm{mmCL}$ lebih kecil dibandingkan ukuran rata-rata pertama kali matang gonad (Lm) sebesar 39,63 mmCL, menunjukkan sebagian besar udang tertangkap sebelum memijah. Tingkat pemanfaatan udang windu berada pada tahap lebih tangkap (overfishing) dengan nilai laju pengusahaan (E) sebesar 0,65 pada jantan dan 0,77 pada betina, sehingga disarankan untuk melakukan penangkapan udang windu pada ukuran panjang karapas e $\geq 39 \mathrm{~mm}$ dan jika tertangkap udang pada ukuran $<39 \mathrm{~mm}$, udang sebaiknya dilepas kembali.

Kata Kunci: Balikpapan; dinamika populasi; laju pengusahaan; lebih tangkap; udang windu

\section{DISTRIBUSI DAN POTENSI SUMBER DAYA IKAN PELAGIS DI WILAYAH PENGELOLAAN PERIKANAN NEGARA REPUBLIK INDONESIA 573 (WPP NRI 573) SAMUDERA HINDIA}

Asep Ma'mun

JPPI Maret 2017, Vol 23 No. 1, Hal. 47-56

\section{ABSTRAK}

Pengelolaan perikanan tangkap yang lestari membutuhkan informasi potensi dan pola penyebaran sumber daya ikan yang dimanfaatkan. Penelitian ini bertujuan untuk mengetahui distribusi dan potensi sumber daya ikan pelagis di WPP NRI 573 (perairan Samudera Hindia) dengan metode akustik. Hasil penelitian menunjukan, penyebaran densitas cukup tinggi untuk ikan pelagis ditemukan di perairan selatan Pangandaran hingga wilayah Jogjakarta. Sumber daya ikan pelagis kecil yang terdeteksi didominasi oleh ukuran ikan dengan kisaran panjang antara $25-28 \mathrm{~cm}$ dan ikan pelagis besar di dominasi oleh ukuran ikan $28-31 \mathrm{~cm}$. Nilai rata-rata kepadatan stok untuk ikan pelagis kecil $0,041 \mathrm{ton} / \mathrm{km}^{2}$ dan ikan pelagis besar sebesar 0,14 ton/ $\mathrm{km}^{2}$. Potensi lestari ikan pelagis kecil sebesar 292.092 ton/tahun dan ikan pelagis besar sebesar 505.941 ton/ tahun. Nilai tersebut dapat dijadikan dasar dalam upaya pengelolaan dan pemanfaatan perikanan pelagis.

Kata Kunci: Potensi; sebaran; ikan pelagis; hidroakustik; WPP NRI 573 


\section{APLIKASI MODEL SURPLUS PRODUKSI NON- EKUILIBRIUM PADA PERIKANAN LAYANG (Decapterus macrosoma) DI LAUT JAWA}

\author{
Suherman Banon Atmadja \\ JPPI Maret 2017, Vol 23 No. 1, Hal. 57-66
}

\section{ABSTRAK}

Ikan layang (Decapterus macrosoma) dikelompokkan sebagai ikan pelagis yang menyukai habitat oseanik. Kajian ini membahas pendugaan biomassa dengan pendekatan model surplus produksi (MSY) pada spesies layang berdasarkan himpunan data runtut CPUE dan produksi perikanan pukat cincin yang berasal dari Pekalongan dan Juwana selama kurun waktu 19762009. Analisis menggunakan pendekatan nonekuilibrium dengan bantuan perangkat aplikasi ASPIC 7. Hasil penelitian menunjukan sejak tahun 1991 sampai dengan 2005 , status biomassa cenderung terus menurun dan tingkat eksploitasi telah melampaui ambang batas untuk menentukan pengelolaan dengan besaran keseimbangan Fmsy dan Bmsy =1. Sejak 2006, penurunan secara drastis baik jumlah armada pukat cincin maupun aktivitas penangkapannya telah memberikan peluang terhadap pemulihan stok menuju tingkat biomassa optimal. Keterbatasan kemampuan pengendalian terhadap dinamika perikanan berakibat pada peningkatan upaya penangkapan, perubahan kapasitas maupun taktik penangkapan. Pergeseran teknologi tersebut cenderung lebih rasional untuk peningkatan produktivitas dan abai terhadap tingkat mortalitas penangkapan yang sedang berjalan $\left(F_{t}\right)$. Untuk itu, upaya pengendalian yang lebih konservatif tentang risiko terhadap pembiaran pola eksploitasi yang sedang berjalan sangat diperlukan. Evaluasi terhadap jumlah armada aktif merupakan landasan untuk mendapatkan status pemanfaatan yang sedang berjalan dan penutupan izin masuknya armada baru merupakan tindakan pengelolaan patut dilakukan untuk memperbesar peluang pemulihan stok pada tingkat optimal.

Kata Kunci: Surplus produksi; non-equilibrium; ikan layang; Laut Jawa 